\title{
Decreased mitochondrial gene expression in isolated islets of rats injected neonatally with streptozotocin
}

\author{
N. Welsh ${ }^{1}$, S. Pääbo ${ }^{2}$ and M. Welsh ${ }^{1}$ \\ ${ }^{1}$ Department of Medical Cell Biology, Uppsala University, Uppsala, Sweden, \\ 2 Zoologisches Institute, University of Munich, Munich, FRG
}

\begin{abstract}
Summary. The aim of the present study was to evaluate the possible role of the expression of the mitochondrial genome for the regulation of insulin production in the pancreatic Beta cell. For this purpose, islets of Langerhans were isolated from adult control rats and rats injected neonatally with streptozotocin and the islet contents of specific mitochondrial DNAs and RNAs together with nuclear-encoded RNAs were determined. The contents of mitochondrial cytochrome $b$ mRNA, the mitochondrial $12 \mathrm{~S}$ rRNA and insulin mRNA were all $30-40 \%$ lower in islets isolated from the streptozotocin-treated rats as compared to islets from control rats. In contrast, the nuclear mRNA coding for the mitochondrial adenine nucleotide translocator was not decreased in the streptozotocin-treated rats. Contents of mitochondrial DNA, as assessed by the Southern blotting technique, were markedly decreased in the streptozotocin islets. Sequence analysis of mitochondrial DNA from streptozotocin islets
\end{abstract}

and control islets however, did not reveal any differences in nucleotide sequences. In control islets the contents of mitochondrial cytochrome $b$ mRNA increased in response to a high glucose concentration during a 4-h incubation period. Serum deprivation or the addition of theophylline or 4-phorbol 12-myristate 13-acetate failed to affect the cytochrome $b$ mRNA contents in vitro. It is concluded that islets of streptozotocin-treated rats contain low contents of mitochondrial DNA and RNA. Since a lower mitochondrial RNA content may result in a diminished oxidative capacity, it is conceivable that a deficiency of this messenger may contribute to the development of insulin deficiency.

Key words: Pancreatic islets, streptozotocin, mitochondrial DNA, mitochondrial RNA, insulin mRNA, adenine nucleotide translocator mRNA.
The rat mitochondrial genome is more than 16 kilobase long and contains sequences that code for 22 tRNAs, the $12 \mathrm{~S}$ and $16 \mathrm{~S}$ rRNAs, and 13 proteins [1]. The proteins have been identified as cytochrome $b$ (Cyt b) and subunits of cytochrome-c-oxidase, NADH:ubiquinone-reductase and ATP-synthase [2]. Transcription of mitochondrial (mt) DNA is initiated at two different promoters located within the displacement loop (D-loop) region [3] and requires transcription factors and an RNA-polymerase [4-5]. This process leads to the formation of two polycistronic messages, one for each strand, in which the tRNA sequences serve as punctuation signals for rRNA and mRNA during processing [6]. It has recently been reported that expression of mitochondrial genes in myoblasts and adipose tissue exhibit sequential changes during embryogenesis $[7,8]$. Moreover, mitochondrial RNA transcription was shown to be increased in response to chronic stimulation in skeletal muscle $[9,10]$, by thyroid hormone [11] and glucocorticoids [12] in adult liver cells, and by fetal calf serum and polyoma virus transfection in different cell lines $[13,14]$. Thus, replication and transcription of mtDNA appears to be strictly regulated in several types of differentiated cells.

Oxidative mitochondrial metabolism is of decisive importance for the regulation of insulin production in the pancreatic Beta cell [15]. In view of this, the aim of the present work was to study the regulation of mitochondrial gene expression in isolated rat islets. We have also compared steady-state levels of mitochondrial RNA species in islets from rats injected neonatally with streptozotocin (STZ) with those of control islets. Administration of STZ to new-born rats leads to an initial period of profound Beta cell loss and overt diabetes followed by a marked regeneration of the Beta cells and a restoration of the glucose tolerance [16-17]. However, after some 6 weeks, a gradual deterioration of glucose tolerance and mild hyperglycaemia develops. Neonatally STZtreated rats have therefore been widely used as a model for human Type 2 (non-insulin-dependent) diabetes mellitus. 


\section{Materials and methods}

\section{Chemicals}

Glyoxal, poly(A), polyvinylpyrrolidione, salmon sperm DNA and Hepes were from Sigma Chemical Co., (St. Louis, Mo., USA) GeneScreen hybridization transfer membrane was obtained from New England Nuclear, (Boston, Mass., USA) Ficoll 400 was from Pharmacia Fine Chemicals (Uppsala, Sweden). $\left[\alpha-{ }^{32} \mathrm{P}\right] \mathrm{dCTP}$ $(3000 \mathrm{Ci} / \mathrm{mmol}),\left[{ }^{35} \mathrm{~S}\right]-\mathrm{dATP} \alpha \mathrm{S}$ and multiprime labelling reactions were supplied by Amersham (Amersham, Bucks, UK). Sequenase was from United States Biochemicals (Cleveland, Ohio, USA). Collagenase (EC 3.4.24.3) was obtained from Boehringer Mannheim (Mannheim, Germany) and Hanks' balanced salt solution was supplied by Statens Bakteriologiska Laboratorium (Stockholm, Sweden). Culture medium RPMI 1640 and L-glutamine were from Flow Laboratories (Irvine, Ayrshire, UK). All other chemicals of analytical grade were obtained from E. Merck (Darmstadt, FRG).

\section{Animals}

Sprague-Dawley rats were obtained from our local colony. Rats were injected i.p. on their first day of life with STZ dissolved in $50 \mu \mathrm{l}$ citrate buffer in a dose of $100 \mathrm{mg} \mathrm{STZ} / \mathrm{kg}$ body weight. Control rats were from the same litters and received citrate buffer only. On day 4 of life the experimental animals were tested for glucosuria using Clinistix (Ames-Miles, Slough, Bucks, UK). Only animals exhibiting a $3+$ reaction were used. At $4-5$ months of age, male rats were killed by cervical dislocation.

\section{Preparation of isolated islets}

Islets were isolated on Ficoll gradients [18] from collagenase digested pancreata [19] of male Sprague-Dawley rats. The islets were picked free from other pancreatic tissue and either maintained in Hanks' salt solution until further use or cultured free-floating in RPMI 1640 containing $10 \%$ calf serum, $2 \mathrm{mmol} / \mathrm{l}$ glutamine, benzylpenicillin $(100 \mathrm{U} / \mathrm{ml})$, and streptomycin $(0.1 \mathrm{mg} / \mathrm{ml})$.

\section{Southern blot analysis}

To freshly isolated islets in groups of 200 was added $200 \mu \mathrm{L}$ of $4.3 \mathrm{~mol} / \mathrm{l}$ guanidinium isotniocyanate, $2 \%$ sarcosyl, $3 \mathrm{mmol} / \mathrm{l}$ EDTA and $10 \mathrm{mmol} / \mathrm{l}$ Tris (pH 8.0$)$ and the samples were incubated for $15 \mathrm{~min}$ at $37^{\circ} \mathrm{C}$. Ammonium acetate $(0.55 \mathrm{~mol} / \mathrm{l})$ was added and the incubation was continued for another $2 \mathrm{~h}$. The DNA was precipitated with one volume of ethanol, re-dissolved and reprecipitated with 2 volumes of ethanol before digestion with EcoR1. Equal amounts of DNA (1.0-2.0 $\mu \mathrm{g})$ were then electrophoresed on $0.8 \%$ agarose gels. The gels were stained with ethidium bromide and inspected with ultra violet light illumination. The gels were treated with $0.5 \mathrm{~mol} / \mathrm{NaOH}$ and blotted onto GeneScreen membranes which were baked at $80^{\circ} \mathrm{C}$ for $2 \mathrm{~h}$. The membranes were hybridized to a $\left.{ }^{32} \mathrm{P}\right] \mathrm{dCTP}$ labelled Cyt b probe [20]. After washing, the membranes were exposed to Hyperfilm-MP for autoradiography and densitometry.

\section{Northern blot and dot-blot analysis}

For Northern blot analysis, freshly isolated islets in groups of 300-500 were washed in phosphate buffered saline (PBS) and solubilized in $4 \mathrm{~mol} / \mathrm{l}$ guanidinium isothiocyanate as described by Maniatis et al. [21]. Total islet RNA was isolated by overnight centrifugation through a cesium chloride cushion $(5.7 \mathrm{~mol} / \mathrm{l})$. The RNA pellet was suspended in $1 \%$ sodium dodecyl sulphate (SDS), $5 \mathrm{mmol} / \mathrm{l}$ EDTA and $20 \mathrm{mmol} / 1$ Tris, $\mathrm{pH} 7.5$ and extracted with an equal vol- ume phenol/chloroform/isoamylalcohol ( $25: 24: 1$, by volume). The RNA was quantified spectrophotometrically at $260 \mathrm{~nm}$ (typical yield of RNA was $4-10 \mu \mathrm{g})$ and equal amounts of RNA $(2-4 \mu \mathrm{g})$ were electrophoresed on $1 \%$ agarose gels containing formaldehyde [21] and biotted to GeneScreen membranes. Differences in islet size were compensated for by applying equal amounts of RNA to the gels. After baking, the membranes were hybridized to [ $\left.{ }^{32} \mathrm{P}\right] \mathrm{dCTP}$ labelled Cyt b cDNA [20], 12 S DNA, rat insulin I cDNA [22] and pAAC9 [23] as a probe for the adenine nucleotide translocator. The $12 \mathrm{~S}$ RNA probe was generated by polymerase chain reaction (PCR) amplification of mouse mitochondrial DNA between nucleotides 15926 and 1478 [24]. After washing, the membranes were exposed to Hyperfilm-MP for autoradiography and densitometry.

For dot-blot analysis, pre-cultured ( $3-5$ days) islets in groups of 75 were washed in PBS and briefly sonicated in $200 \mu \mathrm{l}$ of $0.1 \mathrm{~mol} / 1$ Tris (pH 7.5), $10 \mathrm{mmol} / 1$ EDTA, $1 \%$ SDS. The sonicates were extracted with $200 \mu \mathrm{l}$ of phenol/chloroform/isoamylalcohol. Nucleic acids were precipitated and incubated for $1 \mathrm{~h}$ with $1 \mathrm{~mol} / \mathrm{l}$ glyoxal at $50^{\circ} \mathrm{C}[25-26]$. The samples were then diluted with 3 volumes of $20 \times$ SSC and bound to GeneScreen membranes for hybridization with the labelled Cyt b probe and autoradiography.

\section{Mitochondrial DNA sequencing}

DNA from control and STZ islets was isolated as given above. Approximately $50 \mathrm{ng}$ DNA was used as a template for enzymatic amplification with a thermostable Thermus aquaticus (Taq) DNA polymerase (Perkin Elmer Cetus, Norwalk, Conn., USA). The amplification cycles had the profile $94^{\circ} \mathrm{C}, 1 \mathrm{~min} ; 37^{\circ} \mathrm{C}, 3 \mathrm{~min} ; 72^{\circ} \mathrm{C}, 1 \mathrm{~min}$ and the following 28 cycles had the profile $94^{\circ} \mathrm{C}, 1 \mathrm{~min} ; 55^{\circ} \mathrm{C}, 2 \mathrm{~min}$; $72^{\circ} \mathrm{C}, 1 \mathrm{~min}$. The following two oligonucleotide primers were employed in the reactions: 5'CCCGAATTCTTGTCTATGAGGATAAAT and GGGGGATCCGTAACGGGTCATCGC CCA. The sequences of the oligonucleotides are taken from Koike et al. [27] and represent a DNA segment surrounding the replication origin of rat mtDNA. The amplification products were analysed on agarose gels and DNA fragments of the expected size were excised and electro eluted. DNA fragments were then digested with EcoRI and BamHI and cloned into EcoRI/BamHI cut $\mathrm{pSK}^{+}$(bluescript) and sequenced using the Sequenase dideoxy nucleotide sequencing system [28].

\section{Results \\ Effects of insulin secretagogues on steady-state levels of Cyt b $m R N A$}

As assessed by dot-blot analysis, a low serum concentration, theophylline or 4-phorbol 12-myristate 13-acetate (PMA) failed to affect the steady-state levels of Cyt $b$ mRNA in normal control islets during a 4-h incubation period (Fig. 1). On the other hand, $16.7 \mathrm{mmol} / \mathrm{glucose}$ increased the mRNA content with approximately $50 \%$ as compared to $1.67 \mathrm{mmol} / \mathrm{l}$ glucose. This effect appeared to occur only at glucose concentrations above $11.1 \mathrm{mmol} / 1$ since there was no effect between 1.67 and $11.1 \mathrm{mmol} / \mathrm{l}$ glucose (data not shown).

\section{Contents of mitochondrial DNA and RNA in islets from STZ-rats}

EcoRI cleavage of DNA isolated from STZ-islets revealed the same fragment as seen with control DNA (Fig. 2) after hybridization to the Cyt b probe. However, islets from STZ-rats contained markedly less Cyt b DNA 


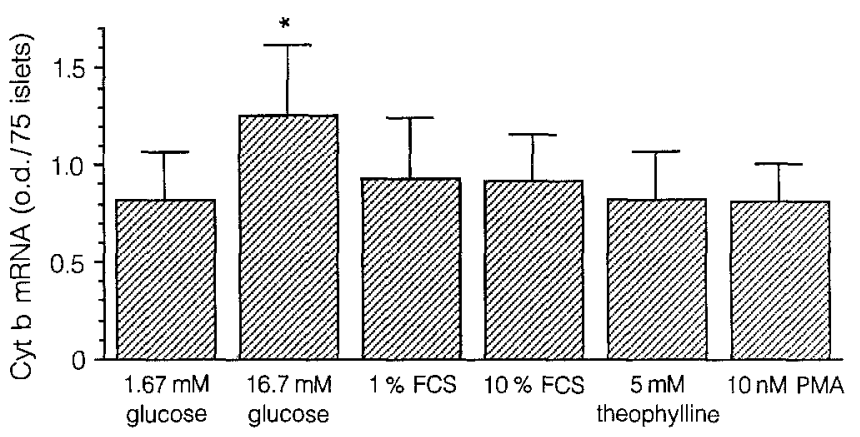

Fig. 1. Effects of insulin secretagogues and Beta-cell mitogens on steady-state levels of cytochrome b (Cyt b) mRNA. Precultured rat islets in groups of 75 were incubated for $4 \mathrm{~h}$ in RPMI 1640 supplemented as shown with different additives. RNA was isolated and blotted onto nylon filters. The filters were hybridized to a labelled Cyt b cDNA probe, washed and the intensities of the spots were determined by means of densitometric scanning. Values are means \pm SEM for $5-6$ observations, * denotes $p<0.05$ using Student's paired $t$-test. FCS $=$ fetal calf serum; PMA $=4$ phorbol 12 -myristate 13-acetate; o. d. = optical density

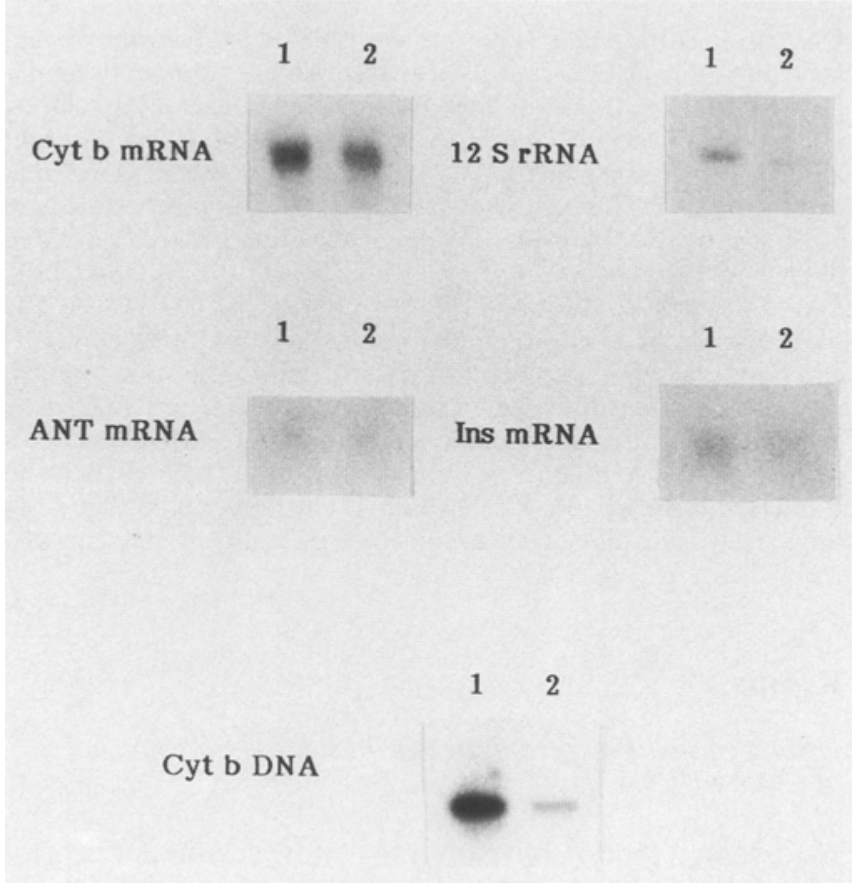

Fig, 2. Northern and Southern blots of RNA and DNA from streptozotocin (STZ)-islets and control islets. Photograph showing contents of the different RNAs and DNA in control islets (lane 1) and STZ-islets (lane 2). Cyt $b=$ cytochrome $b$; ANT mRNA = adenine nucleotide translocator $\mathrm{mRNA}$; Ins $\mathrm{mRNA}=$ insulin $\mathrm{mRNA}$

than control islets (Fig. 2). The results from densitometric scannings of 4-5 separate experiments are given in Figure 3. Also lower than their corresponding controls were Cyt b mRNA and $12 \mathrm{~S}$ rRNA in STZ-islets. The decreases in these two mitochondrial RNAs were of the same mag nitude and less pronounced than that observed in Cyt b DNA. Of the two nuclear encoded mRNAs, insulin mRNA contents were some $40 \%$ lower in the STZ-islets, whereas adenine nucleotide translocator mRNA levels

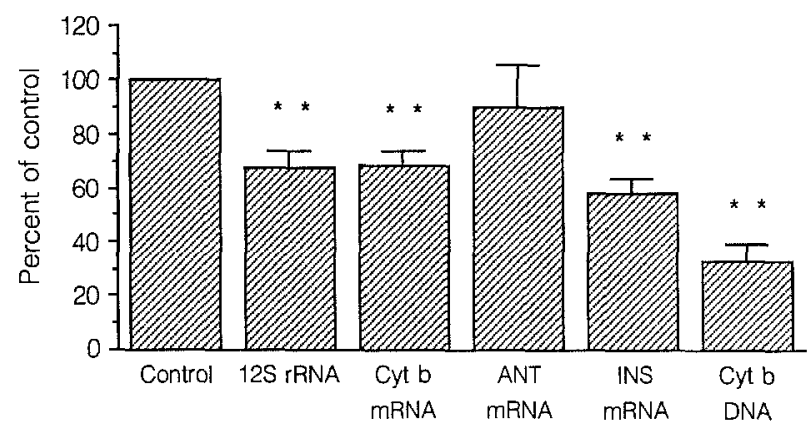

Fig.3. DNA and RNA contents in islets isolated from streptozotocin (STZ)-treated rats as compared to control rats. Islets were isolated from STZ-rats and control rats in parallel and RNA and DNA were isolated as given in Materials and methods. Relative contents of different RNA and DNA species were determined after Northern and Southern blotting and hybridization with labelled probes for 12 S RNA, cytochrome b mRNA, adenine nucleotide translocator mRNA and insulin mRNA. The relative contents of the different species are expressed as a percentage of the corresponding control. Values are means \pm SEM for 4-5 separate observations. ** denotes $p<0.01$ using Student's paired $t$-test. Cyt $\mathrm{b}=$ cytochrome b; ANT mRNA = adenine nucleotide translocator mRNA; Ins mRNA = insulin mRNA

were not significantly decreased compared to control islets (Fig. 2 and 3).

\section{Sequencing of mitochondrial DNA}

DNA fragments of the mitochondrial D-loop derived from three STZ-rats were PCR-amplified and sequenced. The nucleotide sequences were identical to each other and to the sequence of five control rats and are given in Figure 4, track 1 . Since approximately 200 base pairs were sequenced from each STZ-rat, a total of 600 base pairs of STZ-treated mitochondrial DNA was free from any mutations. In track 2, Figure 4, the nucleotide sequence of the same region reported by Koike et al. [27] is given for comparison. The observed differences in the sequences may be explained by intraspecies polymorphism. Three of the four differences are transitions which are expected in mtDNA $[29,30]$.

\section{Discussion}

We have previously reported that culture of isolated rat islets for 7 days at a high glucose concentration increased Cyt b mRNA contents by $40 \%$ [31]. In the present study, the Cyt b mRNA contents were similarly increased by a high glucose concentration after only a 4-h incubation period. When comparing the effects of glucose on the contents of insulin mRNA and Cyt b mRNA, it is known that the effect of glucose on the expression of the insulin gene is marked (three-ten fold) and reaches its maximum after several days $[32,33]$. These obvious differences may, in part, be explained by the rapid turn-over of mtRNA [5], as compared to the low turn-over rate of insulin mRNA [34]. In addition, glucose enhances both the transcription of the 


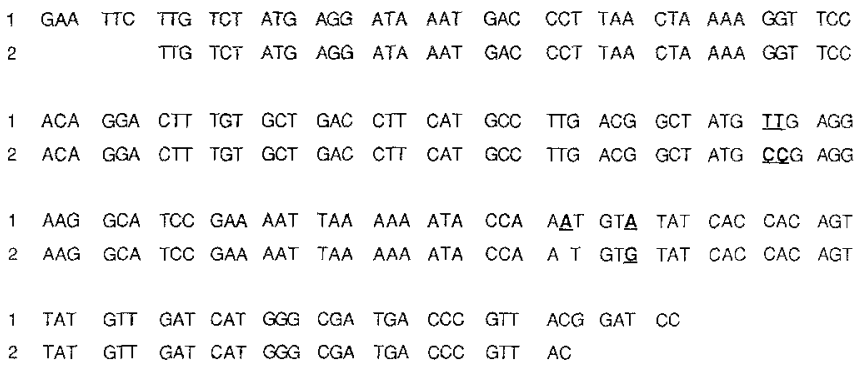

Fig.4. Nucleotide sequence of mtDNA from streptozotocin (STZ)islets. Track 1 shows the nucleotide sequence of a fragment of the Dloop containing region from three STZ-rats and five control rats and corresponds to the $H$-strand $\left(5^{\prime}-3^{\prime}\right)$. Track 2 shows the nucleotide sequence of the same region reported by Koike et al. [27]. Underlined letters represent dissimilarities between the reported and the presently observed nucleotide sequences

insulin gene and the stability of insulin mRNA [34]. We have presently not studied mtRNA transcription rates due to the very limited availability of Beta cells. Therefore, it is unclear whether glucose, in the Beta cell, affects mtRNA-transcription or mtRNA-stability or both. In hepatocytes, however, it has been shown that mitochondrial gene expression is controlled mainly at the level of transcription [11]. The presently observed modest effect of glucose on Cyt b mRNA contents supports the view that glucose exerts its actions mainly by enhancing mtRNA transcription only and not by a combination of both mechanisms. Nevertheless, that Cyt b mRNA and $12 \mathrm{~S}$ rRNA contents in the present investigation were equally decreased in STZ-islets suggests that these two RNA species are not differentially regulated either at the transcriptional level or at the level of degradation.

Kadowaki and Kitagawa recently reported that growth stimulation induced an enhanced mitochondrial gene expression, occurring prior to the S-phase, in a hepatoma cell line [13]. We presently show that the Beta-cell mitogens fetal calf serum, PMA and theophylline do not increase Cyt b mRNA levels. This may, however, be due to the limited growth potential of adult Beta cells, i.e., not enough Beta cell may have entered the G1-phase in response to the mitogens in order to allow an enhanced mitochondrial gene expression of these few cells to be recorded.

The major finding of this investigation is the lowered mtRNA and mtDNA content in islets isolated from STZtreated rats. This decrease probably does not reflect a general attenuation of the expression of mitochondrial proteins since the messenger for the mitochondrial adenine nucleotide translocator was not lowered. Since no morphometric analysis was performed in this study, the relative mitochondrial volume fraction in STZ-islets as compared to control islets remains unknown. Thus, we cannot determine whether the number of DNA molecules per mitochondrium was unchanged or decreased. However, in islets treated in vitro with STZ, the mtDNA contents were decreased without a concomitant decrease in the mitochondrial volume fraction [35]. Although the in vitro STZ model and the neonatal STZ model are dissimilar, the possibility that the number of DNA molecules per mitochondrium is decreased in the neonatal STZ-islet cannot be excluded.

Islets from adult rats treated neonatally with STZ exhibit lower insulin mRNA contents, a decreased insulin biosynthesis and a diminished glucose sensitive insulin release $[16,17,36]$. The impaired insulin production is paralleled by specific impairments of the mitochondrial function manifested in lower glucose oxidation and oxygen uptake rates $[37,38]$. In view of these previous observations and the present findings, it is tempting to propose that STZ, a nitrosourea known to alkylate DNA [39], selectively damages mtDNA, as compared to nuclear DNA, leading to a markedly lower mtDNA content and consequently also a lower mitochondrial gene expression. Interestingly, mtRNA levels were not as markedly depressed as mtDNA levels. This would indicate that the lack of mtDNA is partially compensated for by an enhanced transcriptional efficiency in the STZ-islets. Since we also cannot exclude the possibility of an enhanced translation efficiency, it remains uncertain whether the low mtDNA and mtRNA contents actually represent a deficiency at the protein level. However, assuming that a state of protein deficiency exists, it is possible that lower mtRNA levels cause a lower Beta-cell respiratory capacity, since a blocked expression of mitochondrial gene products in mouse cell lines has been shown to lead to an inhibition of the expression and assembly of most nuclear-coded subunits of the complexes involved in the oxidative phosphorylation [40].

It has been shown that mtDNA is more vulnerable to oxidative damage than nuclear DNA and that methylation of mtDNA occurs at increasing frequencies with increasing age [41, 42]. Moreover, Trounce et al. [43] and Linnane et al. [44] have proposed that cumulative damage to mtDNA could be an important contributor to ageing and degenerative diseases. That STZ would induce multiple mutations in the mitochondrial genome and thereby cause a gradual deterioration of insulin production, however, does not appear likely since we could not detect any mutations within the D-loop region of STZmtDNA. Thus, it seems that STZ induces an all-or-nothing injury to mtDNA, i.e. only the DNA which is essentially undamaged and/or efficiently repaired will survive. We have previously shown that the impaired glucose-sensitive insulin release of STZ-islets was not readily restored during culture at a high-glucose concentration, whereas a restoration occurred during culture at lower glucose concentrations [36]. This suggests that the low mtDNA content of STZ-islets induces a deficient insulin release only when these islets are exposed to a state of high functional demand. Against this background, it appears worthwhile to determine to what extent Type 2 diabetes mellitus in humans is associated with lower mtDNA/mtRNA contents and/or an enhanced mutation frequency of the mitochondrial genome.

Acknowledgements. The Cytochrome b probe was generously provided by Dr. K. Koike, Cancer Institute, Department of Gene Research, Tokyo, Japan and the pAAC9 probe from Dr. H. Wohlrab, Department of Cell Physiology, Boston Biomedical Research Institute, Boston, USA. This study was supported by grants from the Swedish Medical Research Council (12X-109, 12X-8273, 12X-9886), 
the Swedish Diabetes Association, the Hoechst Diabetes Foundation, the Juvenile Diabetes Foundation and the Swedish Society for Medical Research.

\section{References}

1. Gadaleta G, Pepe G, De Candia G, Quagliariello C, Sbisà E, Saccone $C$ (1989) The complete nucleotide sequence of the rattus norvegicus mitochondrial genome: cryptic signals revealed by comparative analysis between vertebrates. J Mol Evol 28: 497516

2. Chomyn A, Cleeter MWJ, Ragan CI, Riicy M, Doolittle RF, Atterdi G (1986) URFG, last unidentified reading frame of human mtDNA codes for an NADH dehydrogenase subunit. Science 234: $614-618$

3. Chang DD, Clayton DA (1984) Identification of primary transcriptional start sites of mouse mitochondrial DNA: accurate in vitro initiation of both heavy- and light-strand transcripts. Mol Cell Biol 6: 1446-1453

4. Yaginuma K, Kobayashi M, Taira M, Koike K (1982) A new RNA polymerase and in vitro transcription of the origin of replication from rat mitochondrial DNA. Nucl Acids Res 10: 7531-. 7542

5. Fisher RP, Clayton DA (1985) A transcription factor required for promoter recognition by human mitochondrial RNA polymerase. Accurate initiation at the heavy-and light-strand promoters dissected and reconstituted in vitro. J Biol Chem 260: 1133011338

6. Ojala D, Montoya J, Attardi G (1981) tRNA punctuation model of RNA processing in human mitochondria. Nature (London) 290: $470-474$

7. Webster KA, Gunning P, Hardeman E, Wallace DC, Kedes L (1990) Coordinate reciprocal trends in glycolytic and mitochondrial transcript accumulations during the in vitro differentiation of human myoblasts. J Cell Physiol 142: 566-573

8. Casteilla I, Champigny O, Boulillaud F, Robelin J, Ricquier D (1989) Sequential changes in the expression of mitochondrial protein mRNA during the development of brown adipose tissue in bovine and ovine species. Biochem J 257: 665-671

9. Williams RS, Salmons S, Newsholme EA, Kaufman RE, Mellor J (1986) Regulation of nuclear and mitochondrial gene expression by contractile activity in skeletal muscle. J Biol Chem 261: $376-380$

10. Hood DA, Zak R, Pette D (1989) Chronic stimulation of rat skeletal muscle induces coordinate increases in mitochondrial and nuclear mRNAs of cytochrome-c-oxidase subunits. Eur $\mathrm{J}$ Biochem 179: 275-280

11. Mutvei A, Kuzela S, Nelson BD (1989) Control of mitochondrial transcription by thyroid hormone. Eur J Biochem 180: 235-240

12. Minchenko AG (1989) The time-dependent stimulating action of hydrocortisone on mitochondrial RNA biosynthesis in the rat liver. Probl Endokrinol 35: 72--77

13. Kadowaki T, Kitagawa Y (1988) Enhanced transcription of mitochondrial genes after growth stimulation and glucocorticoid treatment of Reuber hepatoma H-35. FEBS Lett 233:51-56

14. Glaichenhaus N, Leopold P, Cuzin F (1985) Increased levels of mitochondrial gene expression in rat fibroblast cells immortalized or transformed by viral and cellular oncogenes. EMBO J 5: 1261-1265

15. Sener A, Malaisse WJ (1987) Stimulation by D-glucose of mitochondrial oxidative events in islet cells. Biochem J 246: 89-95

16. Portha B (1985) Decreased glucose-induced insulin release and biosynthesis by islets of rats with non-insulin-dependent diabetes: effects of tissue culture. Endocrinology 117: 1735-1741

17. Bonner-Weir S, Trent RN, Weir GC (1981) Responses of neonatal rat islets to streptozotocin. Diabetes 30: 64-69

18. Lernmark $\AA$, Nathans A, Steiner DF (1976) Preparation and characterization of plasma membrane-enriched fractions from pancreatic islets. J Cell Biol 17: 606-623
19. Howell SL, Taylor KW (1968) Potassium ions and the secretion of insulin by islets of $\mathrm{L}$ angerhans incubated in vitro. Biochem $\mathrm{J}$ 108: $17-24$

20. Koike K, Kobayashi M, Yaginuma K, Taira M, Yoshida E, Imai M (1982) Nucleotide sequence and evolution of the rat mitochondrial cytochrome $b$ gene containing the ochre termination codon. Gene 20: 177-185

21. Maniatis T, Fritsch EF, Sambrook J (1982) Molecular cloning: a laboratory manual. Cold Spring Harbor Laboratory Press, Cold Spring Harbor, NY

22. Chan SJ, Noyes BE, Agrawal KI, Steiner DF (1979) Construction and selection of recombinant plasmids containing fulllength complementary DNAs corresponding to rat insulins I and II. Proc Natl Acad Sci USA 76:5036 5040

23. Rasmussen B, Wohlrab H (1986) Bovine cardiac mitochondrial ADP/ATP-carrier: two distinct mRNAs and an unusually short 3 'noncoding sequence. Biochem Biophys Res Commun 138: $850-857$

24. Kocher TD, Thomas WK, Meyer AA, Edwards SV, Pääbo S, Villablanca FX, Wilson AC (1989) Dynamics of mitochondrial DNA evolution in animals: amplification and sequencing with conserved primers. Proc Natl Acad Aci USA 86: 6196-6200

25. Thomas P (1980) Hybridization of denatured RNA and small DNA fragments transferred to nitrocellulose. Proc Natl Acad Sci USA 77: 5201-5205

26. White BA, Bancroft FC (1982) Cytoplasmic dot hybridization. Simple analysis of relative mRNA levels in multiple small cell or tissue samples. J Biol Chem 251:8569-8572

27. Kioke K, Kobayashi M, Sekiya T (1979) Cloning and characterization of the replication origin from rat mitochondrial DNA. Cold Spring Harbor Symp Quant Biol 43: 193-201

28. Sanger F, Nicklen S, Coulson AR (1977) DNA-sequencing with chain-terminating inhibitors. Proc Natl Acad Sci USA 74: 5463 5467

29. Brown WM, Prager EM, Wang A, Wilson AC (1982) Mitochondrial DNA sequences of primates: tempo and mode of evolution. J Mol Evol 18: 225-239

30. Brown GG, Simpson MV (1982) Novel features of animal mtDNA evolution as shown by sequences of two rat cytochrome oxidase subunit II genes. Proc Natl Acad Sci USA 79:3246-3250

31. Svensson C, Welsh N, Krawetz SA, Welsh M (1991) Exhibition of specificalterations in activities and $\mathrm{m}$ RNA levels of rat islet glycolytic and mitochondrial enzymes in three different in vitro model systems for attenuated insulin release. Diabetes 40:771-776

32. Welsh M (1989) Glucose regulation of insulin gene expression. Diabète Metab 15: 367-371

33. Brunstedt J, Chan S (1982) Direct effect of glucose on the preproinsulin mRNA level in isolated pancreatic islets. Biochem Biophys Res Commun 106: 1383-1389

34. Welsh M, Nielsen DA, MacKrell AJ, Steiner DF (1985) Control of insulin gene expression in pancreatic $\beta$-cells and in an insulin producing cell line, RIN-5F cells. J Biol Chem 260: 13590-13594

35. Moreira JE, Hand AR, Borg LAH, Sandler S, Welsh M, Welsh N, Eizirik DL (1991) Decrease of insulin-containing secretory granules and mitochondrial gene expression in mouse pancreatic islets maintained in culture following streptozotocin exposure. Virchows Arch, In press

36. Welsh N, Hellerström C (1990) In vitro restoration of insulin production in islets from adult rats treated neonatally with streptozotocin. Endocrinology 126: 1842-1848

37. Portha B, Giroix M-H, Serradas P, Welsh N, Hellerström C, Sener A, Malaisse WJ (1988) Insulin production and glucose metabolism in isolated pancreatic islets of rats with NIDDM. Diabetes 37: 1226-1233

38. Giroix M-H, Rasschairt J, Bailbe D, Leclercq-Meyer V, Sener A, Portha B, Malaisse WJ (1991) Impairment of glycerol phosphate shuttle in islets from rat with diabetes induced by neonatal streptozocin. Diabetes 40: 227-232

39. LeDoux SP, Woodley SE, Patton NJ, Wilson GL (1986) Mechanisms of nitrosourea-induced $\beta$-cell damage. Alterations in DNA. Diabetes 35: $866-872$ 
40. Hayashi J, Tanaka M, Sato W, Ozawa T, Yonekawa H, Kageawa Y, Otha S (1990) Effects of ethidium bromide treatment of mouse cells on expression and assembly of nuclear-coded subunits of complexes involved in the oxidative phosphorylation. Biochem Biophys Res Comm 167: 216-221

41. Richter C, Park J-W, Ames BN (1988) Normal oxidative damage to mitochondrial and nuclear DNA is extensive. Proc Natl Acad Sci USA 85: 6465-6467

42. Park J-W, Ames BN (1988) 7-Methylguanine adducts in DNA are normally present at high levels and increase on aging: analysis by HPLC with electrochemical detection. Proc Natl Acad Sci USA 85: 7467-7470

43. Trounce I, Byrne E, Marzuki S (1989) Decline in skeletal muscle mitochondrial respiratory chain function: possible factor in ageing. Lancet I: 637-641
44. Linnane AW, Marzuki S, Ozawa T, Tanaka M (1989) Mitochondrial DNA mutations as an important contributor to ageing and degenerative diseases. Lancet I: 642-645

Received: 1 March 1991

and in revised form: 3 June 1991

Dr. N. Welsh

Department of Medical Cell Biology

Biomedicum, P.O.Box 571

S-751 23 Uppsala

Sweden 